\title{
Miscarriage following dengue virus 3 infection in the first six weeks of pregnancy of a dengue virus-naive traveller returning from Bali to Italy, April 2016
}

M Zavattoni ${ }^{12}$, F Rovida ${ }^{12}$, G Campanini ${ }^{1}$, E Percivalle ${ }^{1}$, A Sarasini ${ }^{1}$, G Cristini ${ }^{3}$, LR Tomasoni ${ }^{4}$, F Castelli ${ }^{4}$, F Baldanti $^{15}$

1. Molecular Virology Unit, Microbiology and Virology Department, Fondazione IRCCS Policlinico San Matteo, Pavia, Italy

2. These authors contributed equally to this work

3. Department of Infectious Diseases, Spedali Civili General Hospital, Brescia, Italy

4. University Department of Infectious and Tropical Diseases, University of Brescia and Spedali Civili General Hospital, Brescia, Italy

5. Department of Clinical, Surgical, Diagnostic and Pediatric Sciences, University of Pavia, Pavia, Italy

Correspondence: Fausto Baldanti (f.baldanti@smatteo.pv.it)

Citation style for this article:

Zavattoni M, Rovida F, Campanini G, Percivalle E, Sarasini A, Cristini G, Tomasoni LR, Castelli F, Baldanti F. Miscarriage following dengue virus 3 infection in the first six weeks of pregnancy of a dengue virus-naive traveller returning from Bali to Italy, April 2016. Euro Surveill. 2016;21(31):pii=30308. DOI: http://dx.doi. org/10.2807/1560-7917.ES.2016.21.31.30308

Article submitted on 13 July 2016 / accepted on 03 August 2016 / published on 04 August 2016

We report miscarriage following dengue virus (DENV)-3 infection in a pregnant woman returning from Bali to Italy in April 2016. On her arrival, the woman had fever, rash, asthenia and headache. DENV RNA was detected in plasma and urine samples collected the following day. Six days after symptom onset, she had a miscarriage. DENV RNA was detected in fetal material, but in utero fetal infection cannot be demonstrated due to possible contamination by maternal blood.

\section{Case description}

A woman in her 30 s returned from Bali to Italy in early April 2016. The day she left Bali and arrived in Italy, she became ill with fever $\left(>38.5^{\circ} \mathrm{C}\right)$, rash, asthenia and headache, which lasted for a further five days. She had had her last menstrual period mid-February and discovered she was seven-weeks pregnant on her return from Bali, having performed an off-the-shelf pregnancy test as soon as she landed in Italy. The day of her arrival (during the first 24 hours of fever), she presented at a hospital emergency department in Brescia (Lombardy region), where ultrasonographic examination confirmed she was pregnant. The size and cardiac activity of the embryo was normal. All haematochemical tests of the woman were normal (including white blood cell and platelet count), a rapid diagnostic test (BinaxNOW Malaria, Alere, Scarborough, United States) for malaria was negative, TORCH assays were negative for cytomegalovirus and toxoplasmosis, while she was immune to herpes simplex-1 virus and rubella virus, and she was discharged. Because of persistence of her symptoms, including a high temperature $(>38.5$ $\left.{ }^{\circ} \mathrm{C}\right)$, she returned the following day: she was mildly neutropenic but not platelet depleted. Ultrasound confirmed a live embryo. Blood and urine samples were collected and referred to the regional reference laboratory (Fondazione IRCCS Policlinico San Matteo in Pavia) to investigate potential arbovirus infections. Three days later, her platelet level started to fall, with the lowest count (30,000/ $\mathrm{LL}$; norm: $130,000-400,000 /$ $\mu \mathrm{L})$ recorded three days after that.

Three days after arriving in Italy, the woman's spouse, who had also been travelling in Bali, reported similar symptoms.

\section{Laboratory findings}

The diagnostic assessment included the following: (i) detection of dengue virus (DENV) $1-4$ IgM and IgG antibodies in serum samples (using dengue virus IgM Capture DxSelect and dengue virus IgG DxSelect, Focus Diagnostics, United States), as well as detection of Zika virus (ZIKV) IgM and IgG antibodies (AntiZika virus ELISA (IgM) and Anti-Zika virus ELISA (IgG), Euroimmun, Germany); (ii) serology results were confirmed by neutralisation assay [1]; (iii) detection of DENV NS1 antigen in serum samples (dengue NS1 Ag STRIP, BIO RAD, France); (iv) detection of DENV RNA and ZIKV RNA in plasma and urine samples using a pan-flavivirus hemi-nested reverse transcription(RT)polymerase chain reaction (PCR) targeting a conserved region of the $\mathrm{NS}_{5}$ gene [2] as well as virus-specific real-time RT-PCRs, targeting a conserved region in the 3' untranslated region of DENV 1-4 [3] and a portion of the envelope protein gene of ZIKV [4]; and (v) sequencing of positive pan-flavivirus amplicons.

DENV infection was diagnosed in the woman and her spouse, while ZIKV infection was ruled out. 
Virological results in two dengue virus-infected patients returning from Bali to Italy, April 2016

\begin{tabular}{|c|c|c|c|c|c|c|c|c|c|c|c|}
\hline \multirow[t]{2}{*}{ Patient } & \multirow{2}{*}{$\begin{array}{l}\text { Days after symptom } \\
\text { onset samples taken }\end{array}$} & \multirow[t]{2}{*}{$\lg G$} & \multirow[t]{2}{*}{$\lg M$} & \multirow{2}{*}{$\begin{array}{l}\text { DENV-3 } \\
\text { NT Ab }\end{array}$} & \multirow{2}{*}{$\begin{array}{l}\text { NS1 } \\
\text { antigen }\end{array}$} & \multicolumn{3}{|c|}{$\begin{array}{c}\text { Dengue virus-specific real-time } \\
\text { RT-PCR } \\
\text { Number of copies } / \mathrm{mL}\end{array}$} & \multicolumn{3}{|c|}{ Pan-flavivirus RT-PCR } \\
\hline & & & & & & Plasma & Urine & Fetal material ${ }^{\mathrm{b}}$ & Plasma & Urine & $\begin{array}{c}\text { Fetal } \\
\text { material }\end{array}$ \\
\hline \multirow{4}{*}{ Woman ${ }^{a}$} & $\begin{array}{c}+2 \\
(7 \text { WOP }) \\
\end{array}$ & Neg & Neg & $\ll 1: 10$ & Pos & $7.0 \times 10^{8}$ & $\begin{array}{c}1.0 \times \\
10^{3}\end{array}$ & NA & Pos & Pos & NA \\
\hline & $\begin{array}{c}+9 \\
(8 \text { WOP) } \\
\end{array}$ & ND & ND & ND & ND & ND & ND & $3.9 \times 10^{3}$ & ND & ND & Pos \\
\hline & +12 & Neg & Pos & $1: 80$ & Neg & 20 & $\begin{array}{c}1.6 \times \\
10^{3}\end{array}$ & NA & Pos & Pos & NA \\
\hline & +24 & Pos & Pos & $1: 160$ & Neg & Neg & $\mathrm{Neg}$ & NA & Pos & Pos & NA \\
\hline \multirow{2}{*}{$\begin{array}{l}\text { Woman's } \\
\text { spouse }\end{array}$} & +5 & Neg & Pos & $1: 20$ & Pos & Neg & $\begin{array}{c}6.7^{x} \\
10^{2}\end{array}$ & NA & Pos & Pos & NA \\
\hline & +21 & Pos & Pos & $1: 160$ & Neg & Neg & $\mathrm{Neg}$ & NA & Pos & Pos & NA \\
\hline
\end{tabular}

DENV: dengue virus; NA: not applicable; ND: not done; Neg: negative; NT Ab: neutralising antibody titre; Pos: positive; RT-PCR: reverse transcription-polymerase chain reaction; WOP; weeks of pregnancy.

a The woman had a miscarriage six days after symptom onset.

b Tested after miscarriage.

Two days after symptom onset, the woman's serum tested negative for DENV IgG and IgM, while NS1 antigenaemia and high levels of DENV RNA (7.0 × 108 copies $/ \mathrm{mL}$ ) were detected in her plasma (Table). DENV RNA was detected in her urine $(1.0 \times 103$ copies $/ \mathrm{mL})$.

Sequencing of amplicons from the woman's plasma and urine confirmed infection by a DENV-3 serotype (GenBank accession number KX583642-KX583643). Interestingly, the DENV RNA load in her plasma was the highest observed at our institution for several years (the median value of 10 sequential recent imported DENV cases is reported for comparison: $3.1 \times 104$ DENV RNA copies/mL; range: $8.8 \times 102$ to $5.4 \times 106$ copies/ $\mathrm{mL}$ ). In addition, DENV was isolated from the plasma sample.

Six days after symptom onset, the woman had a miscarriage: there was no fetal cardiac activity. Three days later, she underwent surgical uterine evacuation and DENV RNA (3.9 $\times 103$ copies $/ \mathrm{mL})$ was detected in the fetal material (GenBank accession number KX583644). A dramatic reduction of DENV RNA load in the woman's plasma was observed six days after the miscarriage (20 copies $/ \mathrm{mL}$ ), while $\mathrm{NS} 1 \mathrm{Ag}$ was negative. At this time (12 days after symptom onset), a plasma sample was positive for DENV IgM, while IgG tests were still negative. DENV real-time RT-PCR to detect DENV RNA in plasma and urine was negative 24 days after symptom onset, whereas it was still positive by pan-flavivirus hemi-nested RT-PCR. DENV IgG seroconversion was observed at that point (Table).

Results from virological and serological tests of her spouse's samples were somewhat different. Five days after symptom onset, DENV NS1 $\mathrm{Ag}$ was positive but DENV RNA in plasma was detected only by pan-flavivirus hemi-nested RT-PCR. In contrast, DENV RNA was detected in urine by both molecular assays. At that time, the sample was DENV IgM positive. Tests 21 days after symptom onset showed that NS1 Ag was negative in plasma and urine, as was DENV RNA using specific real-time RT-PCR, while both samples were positive using the pan-flavivirus hemi-nested RT-PCR. IgG seroconversion was seen at that point (Table).

\section{Background}

The recently reported clusters of microcephaly and other birth defects caused by ZIKV infection in South America [5] have prompted European countries to be on alert for arthropod-born infectious disease risks, especially regarding pregnant travellers and their sexual partners. While chikungunya and West Nile virus infections have not proved to be an increased risk of preterm delivery, miscarriage or low birth weight [6-8], maternal and fetal consequences of DENV infection during pregnancy can be severe [9-12]. In tropical and subtropical regions, four serotypes (DENV 1-4) may be endemic in the same human population and clinical manifestations may range from mild fever in primary infections to haemorrhagic syndromes in reinfections by a different serotype [13]. Other factors, such as high viraemia titre and increased dengue virus-specific serotype replication have been postulated in the pathogenesis of severe disease [14]. In pregnant women living in endemic regions, dengue fever and severe dengue can develop; low platelet counts have been seen in both primary and secondary infections [12]. Fetal death, premature birth and low birth weight, as well as vertical transmission at term causing neonatal thrombocytopenia, have been recorded [10]. In contrast, however, the impact of DENV infection on pregnancy outcome in dengue immunologically naive travellers and the relationship between peak viraemia and pregnancy outcome remain unexplored. 


\section{Discussion}

DENV infection during the first trimester of pregnancy does not reveal a significant risk of vertical transmission of the virus [10]. However, since women in early pregnancy may not be hospitalised, the frequency of vertical transmission remains difficult to estimate [15-18].

The case described in our report chronologically links an acute DENV infection in the first weeks of pregnancy to an unfavourable outcome. It should be borne in mind, however, that one in five of all recognised pregnancies end in miscarriage [19] and maternal hyperthermia is recognised as an independent risk factor for miscarriage [20].

Although DENV RNA was detected in the fetal material tested after the miscarriage, in utero fetal infection cannot be demonstrated due to possible contamination with maternal blood. As fetal death followed the onset of DENV infection, adverse fetal outcome due to possible effects of high maternal viraemia on placental endothelial function cannot be excluded $[14,21]$.

In the global alertness for ZIKV-induced microcephaly [5], DENV infection might represent an additional and underestimated risk factor for pregnancy.

\section{Acknowledgements}

We thank all the technical staff for handling the specimens and performing the assays. We thank Mrs Daniela Sartori for manuscript editing and Mrs Sheila McVeigh for English revision. This work was sustained by Ministero della Salute, Ricerca Corrente grant no. 80206 to Elena Percivalle.

\section{Conflict of interest}

None declared.

\section{Authors' contributions}

Wrote the manuscript: MZ, FR, FB, LRT; managed the patient: LRT, GC; performed laboratory investigations: GC, EP, AS, $F R$; revised the manuscript: $M Z, F R, F B, F C$; coordinated the study: FB, MZ, FR, FC.

\section{References}

1. Timiryasova TM, Bonaparte MI, Luo P, Zedar R, Hu BT, Hildreth SW. Optimization and validation of a plaque reduction neutralization test for the detection of neutralizing antibodies to four serotypes of dengue virus used in support of dengue vaccine development.Am I Trop Med Hyg. 2013;88(5):962-70. DOI: 10.4269/ajtmh.12-0461 PMID: 23458954

2. Scaramozzino N, Crance JM, Jouan A, DeBriel DA, Stoll F, Garin D. Comparison of flavivirus universal primer pairs and development of a rapid, highly sensitive heminested reverse transcription-PCR assay for detection of flaviviruses targeted to a conserved region of the NS 5 gene sequences.J Clin Microbiol. 2001;39(5):1922-7. DOI: 10.1128/JCM.39.5.1922 1927.2001 PMID: 11326014

3. Huhtamo E, Hasu E, Uzcátegui NY, Erra E, Nikkari S, Kantele A, et al. Early diagnosis of dengue in travelers: comparison of a novel real-time RT-PCR, NS1 antigen detection and serology. J Clin Virol. 2010;47(1):49-53. DOI: 10.1016/j.jcv.2009.11.001 PMID: 19963435
4. Lanciotti RS, Kosoy OL, Laven JJ, Velez JO, Lambert AJ, Johnson AJ, et al. Genetic and serologic properties of Zika virus associated with an epidemic, Yap State, Micronesia, 2007. Emerg Infect Dis. 2008;14(8):1232-9. DOI: 10.3201/ eid1408.080287 PMID: 18680646

5. Mlakar J, Korva M, Tul N, Popović M, Poljšak-Prijatelj M, Mraz J, et al. Zika Virus Associated with Microcephaly. N Engl J Med. 2016;374(10):951-8. DOI: 10.1056/NEJMoa1600651 PMID: 26862926

6. Centers for Disease Control and Prevention (CDC). Intrauterine West Nile virus infection--New York, 2002.MMWR Morb Mortal Wkly Rep. 2002;51(50):1135-6.PMID: 12537289

7. O'Leary DR, Kuhn S, Kniss KL, Hinckley AF, Rasmussen SA Pape WJ, et al. Birth outcomes following West Nile Virus infection of pregnant women in the United States: 2003-2004. Pediatrics. 2006;117(3):e537-45. DOI: 10.1542/peds.2005-2024 PMID: 16510632

8. Fritel X, Rollot O, Gerardin P, Gauzere BA, Bideault J, Lagarde L, et al. Chikungunya virus infection during pregnancy, Reunion, France, 2006. Emerg Infect Dis. 2010;16(3):418-25. DOI: 10.3201/eid1604.091403 PMID: 20202416

9. Chitra TV, Panicker S. Maternal and fetal outcome of dengue fever in pregnancy.J Vector Borne Dis. 2011;48(4):210-3.PMID: 22297282

10. Pouliot SH, Xiong X, Harville E, Paz-Soldan V, Tomashek KM, Breart G, et al. Maternal dengue and pregnancy outcomes: a systematic review. Obstet Gynecol Surv. 2010;65(2):107-18. DOI: 10.1097/OGX.ob013e3181cb8fbc PMID: 20100360

11. Tan PC, Rajasingam G, Devi S, Omar SZ. Dengue infection in pregnancy: prevalence, vertical transmission, and pregnancy outcome.Obstet Gynecol. 2008;111(5):1111-7. DOI: 10.1097/ AOG.obo13e31816a49fc PMID: 18448743

12. Kariyawasam S, Senanayake H. Dengue infections during pregnancy: case series from a tertiary care hospital in Sri Lanka.J Infect Dev Ctries. 2010;4(11):767-75. DOI: 10.3855/ jidc.908 PMID: 21252457

13. Bharaj P, Chahar HS, Pandey A, Diddi K, Dar L, Guleria R, et al. Concurrent infections by all four dengue virus serotypes during an outbreak of dengue in 2006 in Delhi, India. Virol J. 2008;5(1):1. DOI: 10.1186/1743-422X-5-1 PMID: 18182120

14. Vaughn DW, Green S, Kalayanarooj S, Innis BL, Nimmannitya S, Suntayakorn S, et al. Dengue viremia titer, antibody response pattern, and virus serotype correlate with disease severity. J Infect Dis. 2000;181(1):2-9. DOI: 10.1086/315215 PMID: 10608744

15. Basurko C, Carles G, Youssef M, Guindi WE. Maternal and fetal consequences of dengue fever during pregnancy. Eur J Obstet Gynecol Reprod Biol. 2009;147(1):29-32. DOI: 10.1016/j. ejogrb.2009.06.028 PMID: 19632027

16. Ismail NA, Kampan N, Mahdy ZA, Jamil MA, Razi ZR. Dengue in pregnancy.Southeast Asian J Trop Med Public Health. 2006;37(4):681-3.PMID: 17121293

17. Waduge R, Malavige GN, Pradeepan M, Wijeyaratne $C N$, Fernando S, Seneviratne SL. Dengue infections during pregnancy: a case series from Sri Lanka and review of the literature.J Clin Virol. 2006;37(1):27-33. DOI: 10.1016/j. jcv.2006.06.002 PMID: 16843056

18. Magara M. Dengue fever in the fields of obstetrics and gynecology.Nippon Igaku Hoshasen Gakkai Zasshi. 1942;3306:1186-90.

19. Giakoumelou S, Wheelhouse N, Cuschieri K, Entrican G, Howie SE, Horne AW. The role of infection in miscarriage. Hum Reprod Update. 2016;22(1):116-33. DOI: 10.1093/humupd/dmv041 PMID: 26386469

20. Edwards MJ. Review: Hyperthermia and fever during pregnancy. Birth Defects Res A Clin Mol Teratol. 2006;76(7):507-16. DOI: 10.1002/bdra.20277 PMID: 16933304

21. Iyngkaran N, Yadav M, Sinniah M. Augmented inflammatory cytokines in primary dengue infection progressing to shock. Singapore Med J. 1995;36(2):218-21.PMID: 7676273

\section{License and copyright}

This is an open-access article distributed under the terms of the Creative Commons Attribution (CC BY 4.0) Licence. You may share and adapt the material, but must give appropriate credit to the source, provide a link to the licence, and indicate if changes were made.

This article is copyright of the authors, 2016. 